\title{
A comparative study of cefixime and ofloxacin $\quad$ T-6 for the treatment of uncomplicated Typhoid fever in Vietnamese children
}

\author{
C.X.T. Phuong ${ }^{1}$, R. Kneen ${ }^{2}$, T.T.T. Mai ${ }^{1}$, P.A. Diep ${ }^{1}$, N.T.T. Ha ${ }^{1}$, P.T.T. Thuy ${ }^{1}$, N.T. Anh', T.T. Thuy ${ }^{1}$, \\ T.D. Luat ${ }^{1}$, D.B. Bethell ${ }^{2}$, N.J. Day ${ }^{2}$, J. Wain ${ }^{2}$, N.J. White ${ }^{2}$, C.M. Parry ${ }^{2}$
}

\begin{abstract}
Abstrak
Demam tifoid (DT) yang disebabkan oleh Salmonella typhi yang resisten terhadap berbagai jenis antibiotika (MDR) merupakan suatu masalah yang umum di Vietnam sejak 1992. Hasil-hasil penelitian terakhir menunjukkan bahwa penggunaan fluorokuinolon (FK) oral, ternyata lebih efektif daripada sefalosporin generasi ketiga yang diberikan secara parenteral. Tetapi adanya kekhawatiran dalam hal penggunaan $F K$ pada anak-anak dan juga telah mulai timbulnya jenis S. typhi yang ternyata resisten terhadap obat asam nalidiksat, yang menimbulkan berkurangnya sensitifitas terhadap $F K$, mengakibatkan dibutuhkannya suatu obat alternatif. Informasi yang ada tentang efektifitas obat sefalosporin generasi ketiga terhadap DT, terbatas. Sejumlah 139 anak dengan diagnosis tersangka DT diikutsertakan dalam suatu penelitian perbandingan secara acak terbuka, dengan sefiksim oral $(20 \mathrm{mg} / \mathrm{kg} / \mathrm{hari}$ dibagi 2 dosis $)$ selama 7 hari dan ofloksasin oral ( $10 \mathrm{mg} / \mathrm{kg} / \mathrm{hari}$ dibagi 2 dosis) selama 5 hari. Hasil pemeriksaan biakan darah ternyata positif untuk S. typhi pada $82 / 139$ (59\%) anak. Hasil isolat S. typhi yang diperoleh, meskipun 70/82 (85\%) di antaranya ternyata MDR, masih sensitif terhadap kedua obat yang dipergunakan untuk penelitian. Pada penderita dengan hasil biakan positif, jangka waktu hingga terjadi penurunan panas rata-rata (SD) adalah 109 (52) jam untuk penderita yng mendapat ofloksasin dan 194 (64) jam untuk penderita yang mendapat sefiksim (p<001). Secara keseluruhan pada kelompok sefiksim terdapat 14 anak yang dapat dikategorikan mengalami kegagalan pengobatan akut serta satu anak yang mengalami kekambuhan, sedangkan pada kelompok ofloksasin terjadi kegagalan pengobatan akut pada 2 anak (RR 7,3 (95\% CI) 1.7 hingga 36,7, p=0,002). Angka kesuksesan secara klinis adalah sebesar 75\% pada sefiksim dan 97\% pada ofloksasin, sedangkan angka kesuksesan secara mikrobiologis masing masing adalah 94 dan 100\%. Tidak dijumpai adanya efek samping yang penting pada penggunaan obat-obat tersebut di atas. Suatu pengobatan selama 5 hari dengan ofloksasin ternyata aman dan efektif pada penderita anak-anak dengan DT tanpa penyulit. Dan suatu pengobatan selama 7 hari dengan menggunakan sefiksim meskipun kurang efektif, merupakan suatu pengobatan alternatif yang berguna untuk penderita anak-anak; terutama bila terjadi resistensi terhadap FK.
\end{abstract}

\begin{abstract}
Typhoid fever (TF) due to multi-drug resistant (MDR) Salmonella typhi has become a common problem in Vietnam since 1992. Recent studies have shown the oral fluoroquinolones $(F Q)$ to be more effective than the parenteral third generation cephalosporins. However, concerns about the use of $F Q$ in children and the emergence in Vietnam of $\mathrm{S}$. typhi isolates resistant to nalidixic acid, with reduced sensitivity to the $F Q$, emphasises the need for effective alternative therapies. There is limited information concerning the effectiveness of the oral third generation cephalosporins for treating TF. 139 children with suspected TF were entered into an open randomised comparison of oral cefixime (20mg/kg/day in 2 divided doses) for 7 days and oral ofloxacin (10mg/kg/day in 2 divided doses) for 5 days. $82 / 139$ (59\%) of the children had a blood culture positive for S. typhi. 70/82 (85\%) of the S. typhi were MDR but all isolates were fully sensitive to both study drugs. In the 82 blood culture positive patients the mean (SD) time for fever clearance was 109(52) hours in those treated with ofloxacin and $197(64)$ in those treated with cefixime $(P<0.001)$. Overall there were 14 acute treatment failures and one relapse in the cefixime group and 2 acute treatment failures in the ofloxacin group (RR $7.3(95 \% \mathrm{CI}) 1.7$ to $36.7, p=0.002)$. The clinical success rate was $75 \%$ with cefixime and $97 \%$ with ofloxacin, and the microbiological success rate was $94 \%$ and $100 \%$ respectively. There were no important side effects attributable to either drug. A 5 day course of ofloxacin proved to be a safe and effective treatinent for children with uncomplicated typhoid fever. $A 7$ day course of cefixime was less effective, but may provide a useful alternative treatment in children, particularly if fluoroquinolone resistance becomes established.
\end{abstract}

\footnotetext{
'Dong Nai Paediatric Centre, Bien Hoa City,

Dong Nai Province Vietnam

${ }^{2}$ Oxford University-Wellcome Clinical Research Unit, Centre for Tropical Diseases, Ho Chi Minh City, Vietnam.
} 


\section{INTRODUCTION}

Multidrug resistant strains of Salmonella typhi have emerged rapidly in Vietnam since 19901. These multidrug resistant strains are resistant to chloramphenicol, ampicillin and co-trimoxazole. The third generation cephalosporins and fluoroquinolones, however, both have good in-vitro activity. Recent studies from Vietnam have demonstrated that in adults, oral fluoroquinolones are more effective than parenteral third generation cephalosporins 2,3 . The fluoroquinolones have also been used effectively in children without short or long term adverse consequences despite earlier concerns about safety ${ }^{4}$. Fluoroquinolones have thus become the treatment of choice for patients with uncomplicated enteric fever in Vietnam. However quinolone resistance has emerged in Vietnam since 19935 . Patients infected with $S$. typhi resistant to the quinolone nalidixic acid are 13.5 times more likely to fail short course ( 3 day) fluoroquinolone treatment ${ }^{6}$ and there is therefore an urgent need to find effective alternative oral therapies. Cefixime, an oral third generation cephalosporin, has been found to be effective in 12 to 14 day courses in typhoid fever in open studies in Egypt and Pakistan 7-9, but there have been no comparative studies between oral third generation cephalosporins and fluoroquinolones. We compared 7 days of cefixime and 5 days of ofloxacin treatment for uncomplicated typhoid fever in Vietnamese children.

\section{METHOD}

This study was conducted at the infectious diseases ward of the Dong Nai Paediatric Centre, Bien Hoa City, Vietnam. This is a paediatric referral hospital for the southern Vietnamese province of Dong Nai, where typhoid fever is endemic. Between July 1995 and April 1996, children (age < 15 years) with suspected uncomplicated typhoid fever were studied. $\mathrm{Pa}$ tients were excluded if they had severe disease, were known to have received or be hypersensitive to quinolones or third generation cephalosporins. Patients who had received treatment with chloramphenicol, ampicillin, first or second generation cephalosporins, or co-trimoxazole were excluded if they had shown a clinical response to these drugs.

Patients were randomised to receive ofloxacin (Oflocet; Roussel, Paris), $10 \mathrm{mg} / \mathrm{Kg} /$ day in 2 divided doses for 5 days or cefixime (Cefspan; Fujisawa, Japan), $20 \mathrm{mg} / \mathrm{Kg} /$ day, in 2 divided doses for 7 days. A complete medical history was obtained and clinical examinations performed by a member of the study team on admission. Axillary temperature and other vital signs were recorded every 6 hours. Patients were examined daily until discharge and symptoms and clinical signs documented. On admission, blood was taken for haematocrit, platelet count, differential white cell count, examination for malaria parasites and Widal test. A blood culture and three stool cultures were taken before and after treatment.

Patients were considered clinically cured if they became afebrile, with resolution of symptoms and no evidence of relapse. Fever clearance time was defined as the time from the onset of treatment until the fever fell to $37.5^{\circ} \mathrm{C}$ or below for at least 24 hours. A clinical failure was defined as a deterioration in clinical condition or a failure of resolution of symptoms requiring further treatment. A microbiological failure was defined as a blood culture positive for $S$. typhi after completion of the treatment regime. Patients were requested to return if fever returned after discharge, and were asked to attend as an outpatient 4 weeks after completion of treatment. A relapse was defined as symptoms suggestive of typhoid fever with a blood culture positive for $S$. typhi during the 28 days after discharge.

\section{RESULTS}

Of the 139 patients with clinically suspected typhoid fever entered into the study, $82(59 \%)$ had blood cultures positive for $S$. typhi. Twenty (24\%) patients with positive blood cultures also had positive pretreatment stool cultures. There were no differences in presenting clinical features between the 2 treatment groups. All isolates of $S$. typhi were susceptible to both the study drugs. In the 82 blood culture isolates the percentage of antimicrobial resistance was: chloramphenicol (87\%), ampicillin (87\%), co-trimoxazole $(83 \%)$, tetracycline $(91 \%)$ and multiple resistance to all four antimicrobial agents $(85 \%)$. There was no resistance to nalidixic acid. The proportion of multi-resistant isolates was the same in both treatment groups.

The mean (SD) fever clearance times were 109 hours (52) in the ofloxacin group compared with 197 hours (64) in the cefixime group (log rank test $c^{2}=39.2$; $\mathrm{p}<0.001)$. There were 17 failures: 14 clinical failures, 2 microbiological failures, and 1 relapse. Fifteen of the treatment failures were in the cefixime group (relative risk $=7.3,95 \%$ CI $1.7-30.7 ; p=0.002$ ). One six year old blood culture positive ofloxacin recipient died unexpectedly on the second day of treatment, 1 
hour before the fourth dose of ofloxacin was due. An autopsy was not performed and a post-mortem clinical diagnosis of myocarditis was made. Sixty-nine patients $(50 \%)$ were assessed at follow up. Ten patients had been febrile within one month of discharge ( 5 in each treatment group) but only one (in the cefixime group) was culture positive for $S$. typhi. He was readmitted and retreated successfully. No follow up stool cultures were positive.

\section{DISCUSSION}

Therapeutic options for multidrug resistant typhoid fever in children are limited. The fluroquinolone drugs, which are the treatment of choice in adults, have traditionally been considered to be unsafe in children. In experimental animals, particularly beagle dogs, fluoroquinolones cause damage to cartilagenous end-plates of the long bones ${ }^{10}$. However, there is no evidence that a similar process occurs in children, and their use is gaining increasing acceptance $4,11,12$. Unfortunately quinolone resistance in $S$. typhi has already developed both in some parts of Vietnam and southern India5,6,13. There is a need for safe, cheap and effective oral alternatives to fluoroquinolones.

Third generation cephalosporins have excellent in-vitro-activity against multidrug resistant $S$. typhi and these antibiotics have been assessed in recent clinical trials ${ }^{13-17}$. Ceftriaxone, available only as the parenteral formulation, has been evaluated most thoroughly in comparative trials and proved inferior to the fluoroquinolones ${ }^{2,3}$. Cefixime, a newer orally administered third generation cephalosporin has been evaluated in three previous trials in children. In open studies in Egypt, cefixime, given for a minimum of 12 days $(20 \mathrm{mg} / \mathrm{kg} /$ day) was effective in $48 / 50(96 \%)$ of patients 7 . An 8 day course $(20-30 \mathrm{mg} / \mathrm{Kg} /$ day) was effective in $56 / 60(93 \%)^{9}$. Cefixime $(10 \mathrm{mg} / \mathrm{Kg} /$ day for 14 days) was compared with ceftriaxone $(65 \mathrm{mg} / \mathrm{Kg} /$ day for 14 days) in 50 Pakistani children. The success rate for both drugs was $80 \% 8$.

This study has demonstrated an overall failure rate of $21 \%$ in cefixime treated children. This was seven times higher than in the ofloxacin group (3\%) although there were no nalidixic acid resistant strains in this series. There were no significant side effects in either group during the course of therapy. The unexplained death of a 6 year old patient receiving ofloxacin is of concern. Myocarditis is a recognised complication of typhoid fever occurring in $2-5 \%$ of cases in some series 18,19 .
This study showed that cefixime $(20 \mathrm{mg} / \mathrm{Kg} / \mathrm{day})$ for 7 days was inferior treatment to ofloxacin $(10 \mathrm{mg} / \mathrm{kg} /$ day $)$ in the treatment of multidrug resistant, but quinolone sensitive, typhoid fever in children. Although a longer course of cefixime may have been more effective, the cure rate still compared favourably with parenteral third generation cephalosporins in multidrug resistant strains and amoxycillin in sensitive strains.

\section{ACKNOWLEDGEMENTS}

We are grateful to the director and staff of the Dong Nai Paediatric Centre, in particular the doctors and nurses of the Infectious Diseases ward. We are also grateful to the Director and staff of the Centre for Tropical Diseases, Cho Quan Hospital, Ho Chi Minh City for support, in particular Drs Tran Tinh Hien, Delia Bethell and Tom Solomon. We thank Professor A. Bryskier, Roussel-Uclaf for donating the ofloxacin tablets used in the study. This study was funded by the Wellcome Trust of Great Britain.

\section{REFERENCES}

1. White NJ, Parry CM. The treatment of typhoid fever. Curr Opin Infect Dis 1996; 9: 298-302.

2. Smith MD, Duong NM, Hoa NTT, et al. Comparison of ofloxacin and ceftriaxone for short-course treatment of enteric fever. Antimicrob Agents Chemother 1994; 38: 171620.

3. Hien TT, Duong NM, Ha HD, et al. A randomized comparative study of fleroxacin and ceftriaxone in enteric fever. Trans R Soc Trop Med Hyg 1994; 88: 464-5.

4. Hien TT, Bethell DB, Hoa NTT, et al. Short course of ofloxacin for treatment of multidrug-resistant typhoid. Clin Infect Dis 1995; 20: 917-23.

5. Wain J, Hoa N, Chinh N, et al. Quinolone resistant Salmonella typhi from Vietnam: molecular basis of resistance and clinical resopnse to treatment. Clin Infect Dis 1997; In press.

6. Chinh NT, Solomon T, Thong MX, et al. Short courses of ofloxacin for the treatment of enteric fever. Trans R Soc Trop Med Hyg 1997; 91: 347-9.

7. Girgis NI, Kilpatrick ME, Farid Z, Sultan Y, Podgore JK. Cefixime in the treatment of enteric fever in children. Drugs Exptl Clin Res 1993; 19: 47-9.

8. Bhutta ZA, Khan IA, Molla AM. Therapy of multidrug-resistant typhoid fever with oral cefixime versus intravenous ceftriaxone. Pediatr Infect Dis J 1994; 13: 990- 4.

9. Girgis NI, Tribble DR, Sultan Y, Farid Z. Short course chemotherapy with cefixime in children with multi-drug resistant Salmonella typhi septicaemia. J Trop Paediatr 1995; 41 : 364-5.

10. Bukhardt JE, Hill MA, Carlton WW, Kesterton JW. His- 
tologic and histochemical changes in articular cartilages of immature beagle dogs dosed with difloxacin fluoroquinolone. Vet Pathol 1990; 27: 162-70.

11. Bethell DB, Hien TT, Phi LT, et al. Effects on growth of single short courses of fluoroquinolones. Arch Dis Child 1996; 74: 44-6.

12. White NJ, Dung NM, Vnh H, Bethell D, Hien TT. Fluoroquinolone antibiotics in children with multidrug resistant typhoid. Lancet 1996; 348: 547.

13. Lewin C, Nandivada L, Aymes S. Multi-resistant Salmonella and fluoroquinolones. J Antimicrob Chemother 1991; 227: 147-9.

14. Islam A, Butler $\mathrm{T}$, Nath $\mathrm{SK}$, et al. Randomized treatment of patients with typhoid fever by using ceftriaxone or chloramphenicol. J Infect Dis 1988; 158: 742-7.

15. Islam A, Butler T, Kabir I, Alam NH. Treatment of typhoid fever with ceftriaxone for 5 days or chloramphenicol for 14 days: a randomized clinical trial. Antimicrob Agents Chemother 1993; 37: 1572-5.

16. Soe GB, Overturf GD. Treatment of typhoid fever and other systemic salmonelloses with cefotaxime, ceftriaxone, cefoperazone and other newer cephalosporins. Rev Infect Dis 1987; 9: 719-36.

17. Lasserre R, Sangalang RP, Santiago L. Three-day treatment of typhoid fever with two different dosages of ceftriaxone, compared to 14 -day therapy with chloramphenicol: a randomized trial. J Antimicrob Chemother 1991; 28: 765-72.

18. Stuart BM, Pullen RL. Typhoid, clinical analysis of 360 cases. Arch Int Med 1946; 78: 629.

19. Khosla SN. The heart in enteric (typhoid) fever. J Trop Med Hyg 1981; 84: 125-31. 